\title{
PEMANFAATAN LIMBAH RUMAH TANGGA DIGUNAKAN UNTUK OBAT DAN KEBERSIHAN
}

\section{THE UTILIZATION OF HOUSEHOLD WASTE USED FOR MEDICINE AND CLEANLINESS}

\author{
Suswanto Ismadi Megah S. ${ }^{1}$, Desi Surlitasari Dewi ${ }^{2}$ Eka Wilany $^{3}$ \\ ${ }^{1}$ (Prodi, Pendikan Bahasa Inggris, Universitas Riau Kepulauan, Indonesia) \\ ${ }^{2}$ (Prodi, Pendikan Bahasa Inggris, Universitas Riau Kepulauan, Indonesia) \\ ${ }^{3}$ (Prodi, Pendikan Bahasa Inggris, Universitas Riau Kepulauan, Indonesia) \\ ${ }^{1}$ megah76@yahoo.co.id, ${ }^{2}$ belldaisy46@gmail.com, ${ }^{3}$ ekaluney@yahoo.co.id
}

\begin{abstract}
Abstrak
Ekoenzim menggunakan bahan baku yang mudah didapat dan murah. Proses fermentasinya yang selama 3 bulan, memang membutuhkan kesabaran tersendiri. Namun, larutan yang dihasilkan memiliki khasiat yang sangat banyak. Dalam proses fermentasinya saja, sudah terus dihasilkan gas $\mathrm{O}_{3}$ (ozon) yang sangat dibutuhkan atmosfer bumi. Larutan ekoenzim bila dicampur dengan air, akan bereaksi serta dapat digunakan sebagai cairan pembersih mulai dari piring, lantai, pakaian, kakus, sampai dengan pencuci rambut dan sabun mandi. Bila dibutuhkan, juga bisa melancarkan saluran air yang tersumbat. Campuran dengan air bila digunakan untuk menyiram tanaman akan memberi hasil buah, bunga, atau panen yang lebih baik.disamping itu juga dapat mengusir serangga-serangga pengganggu. Ampas sampah organik yang sudah difermentasi bisa digunakan sebagai pupuk organik yang baik. Selain ramah lingkungan limbah rumah tangga bisa menjadikan nilai ekonomis bagi warga RW 07 Kec.Sagulung Kota Batam karena selain lingkungan menjadi bersih juga tidak memerlukan biaya yang mahal untuk memperolehnya. Dengan memperkenalkan pengelolan limbah rumah tangga dengan ekoenzim. Manfaat yang ada dari ekoenzim adalah bisa melancarkan saluran air yang tersumbat. Elain itu, bisa juga digunakan untuk menyiram tanaman akan memberi hasil buah, bunga, atau panen yang lebih dan dapat mengusir serangga-serangga pengganggu. Ampas sampah organik yang sudah difermentasi bisa digunakan sebagai bahan untuk kebersihan dan juga sebagai pupuk organik yang baik.
\end{abstract}

Kata Kunci; Pemnafaatan, limbah rumah tangga, obat dan Kebersihan

\begin{abstract}
Ekc-enzyme uses raw materials that are easy to obtain and cheap. The process of fermentation for 3 months, it requires patience. However, the resulting solution has very many properties. In the process of fermentation alone, has been continuously produced 03 gas (ozone) which is needed the earth's atmosphere. Ecoenzyme solution when mixed with water, will react and can be used as a cleaning fluid from plates, floors, clothing, latrines, to washing hair and bath soap. When needed, also can launch a blocked drains. Mixed with water when used to water the plants will give a better fruit, flower, or harvest. Besides, it can also dislodge the intruder insects. The waste of organic waste that has been fermented can be used as a good organic fertilizer. In addition to environmentally friendly household waste can make the economic value for residents $R W 07$ Kec.Sagulung Batam because in addition to the environment to be clean also does not require expensive to obtain it. By introducing the
\end{abstract}


management of household waste with ecoenzymes. The benefits that exist from ecoenzymes is that it can launch a clogged drain. Elain that, can also be used to water the plants will give the fruit, flowers, or more harvest and can repel insect-bugs. The waste of organic waste that has been fermented can be used as material for hygiene and also as a good organic fertilizer.

Keywords; Utilization, household waste, medicine and Cleanliness

\section{PENDAHULUAN}

Menurut Yusuf (2008) untuk meningkatnya aktivitas manusia di rumah tangga menyebabkan semakin besarnya volume limbah yang dihasilkan dari waktu ke waktu. Maka berkenaan dengan hal tersebut pada tanggal 12 Agustus 2017 s/d 03 September 2017 dengan di tetapkan daerah Kel. Sei. Pelunggut Kec. Sagulung Kota Batam, sebagia lokasi kegiatan maka diagendakan suatu kegiatan. Berdasarkan hasil observasi di RW 07 Kel. Sei. Pelunggut dan Kec. Sagulung Kota Batam, ditemukan beberapa pemasalahan diantaranya : masih kurangnya pengelolaan lingkungan dan teknologi tepat guna, adanya kriminalitas remaja, kurangnya pengembangan lapangan olahraga, kurangnya pendidikan keterampilan bagi kelompok wanita, dan kurangnya bimbingan teknis pemasaran. Untuk membatasi kegiatan, melihat banyaknya sampah yang dibuang begitu saja tanpa pengeloalaan yang maksimal untuk dipergunakan untuk menambah kualitas hidup masyarakat lingkungan RW 07 Keluruhan Sei Pelenggut, Kecamatan Sagulung Kota Batam. Tim kami berdiskusi dan membuat skala prioritas untuk melakukan kegiatan yaitu memanfaatkan limbah keluarga agar bisa dimanfaatkan dan bisa menambah nilai ekonomi warga RW 07. Setelah berdiskusi yaitu memanfaatkan limbah sampah yang dapat digunakan untuk pengganti cairan kebersihan yang digunakan untuk mengepel lantai dan membersihkan meja agar terhindar dari lalat dan kecoak. Oleh karea itu tim kami membuat workshop pelatihan pembuatan alat kebersihan dengan memanfaatkan limbah rumah tangga, disamping itu juga limbah rumah tangga bias dimanfaatkan untuk pengobatan pertama untuk sakit perut ringan seperti diare atau mencret.

Setelah melakukan kegiatan dan pemberdayaan diatas kami melihat situasi dan kondisi lingungan di RW 07 Kelurahan Sei. Pelenggut ini sudah menjadi lebih baik dari sebelumnya, seperti lingkugan disekitar RW 07 Kelurahan Sei. Pelenggut sudah mengalami peningkatan tahap demi tahap menuju lingkungan yang bersih sampah disekitar rumah sudah berangsur berkurang dan karena masyarakatnya sudah mulai menyadari arti pentingnya 
kebersihan tersebut. Namun demikian masih menggnakan cara -cara yang instan seperti membeli obat pembersih maupun obat di toko untuk sekedar membersihkan lantai dan sakit perut ringan. Disinilah kami sebagai bagian dari masyarakat berusaha menumbuhkan kesadaran bagi warga masyarakat khususnya lingkungan RW 07 kelurahan sei Pelunggut, terutama para ibu rumah tangga menyadari pola hidup sehat dengan menjaga kebersihan lingkunan untuk kesehatan alam bagi keseimbangan alam baik itu tikus naupun dilaut. Disnilah kami ingin memanfaatkan sampah atau limbah rumah tangga seperti kulit buahbuahan untuk jadikan produk organic yang bermanfaat. Menurut Syafrudin (2004), salah satu alternatif yang bisa dilakukan adalah melaksanakan program pengelolaan sampah berbasis masyarakat, seperti minimasi limbah dan elaksanakan 5 R (Reduce, Reuse, Recycling, Recovery, Replacing). Oleh karena itu, dilihat dari kondisi dan lingkungan yang ada, disini tercetus untuk memanfaatkan limbah rumah tangga seperti kulit buah, misalnya buah jeruk, apel, mangga dll, yang biasanya dibuang dibak sampah dan menjadi bibit penyakit kami arahkan untuk dijadikan benda yang mempunyai nilai guna dan manfaat, yaitu untuk dijadikan sebagi cairan pembersih dan pengobat sakit perut seperti aiare dan mencretmencret. Oleh karena itu kami mendatangkan seorang ahli yang bias memanfaatkan limbah rumah tangga sebagai bahan pembersih dan obat sakit perut dilingkungan RW 07 ini tersebut.

\section{Pemanfaatan Limbah Rumah Tangga}

Pengertian sampah adalah suatu yang tidak dikehendaki lagi oleh yang punya dan bersifat padat. Sementara didalam UU No 18 Tahun 2008 tentang Pengelolaan Sampah. Slamet,(2002) disebutkan sampah adalah sisa kegiatan sehari hari manusia atau proses alam yang berbentuk padat atau semi padat berupa zat organik atau anorganik bersifat dapat terurai atau tidak dapat terurai yang dianggap sudah tidak berguna lagi dan dibuang kelingkungan. Alexander (2001) menjelaskan Jenis sampah yang ada di sekitar kita cukup beraneka ragam, ada yang berupa sampah rumah tangga, sampah industri, sampah pasar, sampah rumah sakit, sampah pertanian, sampah perkebunan, sampah peternakan, sampah institusi/kantor/sekolah, dan sebagainya.

Sedangkan, Hadi (2004), dalam tulisannya yang berjudul sindrom sampah mengatakan bahwa masyarakat bersikap resisten terhadap fasilitas pembuangan sampah, 
dimana sistem pembuangan sampah dijanjikan dinas kebersihan. Tahun 2003, seorang doktor dari Thailand menerima penghargaan dari FAO (lembaga PBB yang mengurus soal panganred) Regional Thailand untuk penemuannya yang bernama eco-enzyme. Dalam bahasa Indonesia kita menyebutnya ekoenzim. Penemuan ini merupakan suatu upaya yang dilakukan Dr. Rosukon Poompanvong bagi lingkungan dengan membantu para petani setempat untuk memperoleh hasil panen yang lebih baik sekaligus ramah lingkungan. Ekoenzim memiliki manfaat yang berlipat ganda. Dengan memanfaatkan sampah organik sebagai bahan bakunya, kemudian dicampur dengan gula aren dan air, proses fermentasinya menghasilkan gas 03 (ozon) dan hasil akhirnya adalah cairan pembersih serta pupuk yang ramah lingkungan. Kegiatan kelompok 17 masyarakat RW 07 kec.Sagulung. seperti dalam kegiatan program fisik dan non fisik, yaitu peningkatan SDM masyarkat RW 07 Kelurahan Sei Pelenggut kecamatan Sagulung. Adapun kegiatan itu berupa kegiatan yang berupa workshop yiatu pemnafaat limbah atau sampah rumah tangga digunakan untuk membuat alat pembersih ataupun bahan baku pel lantai organic. Kegiatan itu dibuat seperti workshop dengan tema "Sosialisasi tentang pengelolaan dan pemanfatan limbah rumah tangga dengan memproduksi ecoenzim dari sampah organik oleh Ibu Lian Tju dari Yayasan Buddha Tzu Chi Indonesia “

\section{METODOLOGI}

Tipe penelitian yang digunakan dalam penelitian ini adalah deskriptif kualitatif, yaitu penelitian yang bermaksud mendeskripsikan fenomena dalam pengelolaan sampah rumah tangga/kawasan, yang terjadi di RW 07 Kelurahan Sei Pelenggut kecamatn Sagulung Kota Batam Langkah kerja yang kami lakukan dalam melaksanakan program kegiatan lebih bersifat terbuka, demokrasi dan musyawarah dengan warga setempat. Sebelum kami melakukan kegiatan, terlebih dahulu kami berdiskusi dengan Ketua RW 07 Kelurahan Sungai Pelunggut Kecamatan Sagulung Kota Batam, kemudian langsung survei kesasaran yang diinginkan untuk mendapatkan kepastian waktu untuk dapat kami melakukan kegiatan yang sesuai dengan program kerja kami. Dilaksanakan pada

Jam : $14.00-16.00$

Tanggal : 13 Agustus 2017 
Tempat : Balai warga RW 07, Kelurahan Sei Pelenggut Kec. Sagulung, Kota Batam

\section{Ruang Lingkup Penelitian}

Pembahasan ruang lingkup masalah dibatasi pada pengelolaan sampah rumah tangga berbasis masyarakat meliputi :

a. Proses perencanaan pengelolaan sampah rumah tangga dari kulit buah-buahan berbasis yang ada dilingukan RW 07 Kelurahan Sungai Pelunggut Kecamatan Sagulung Kota Batam.

b. Pelaksanaan pengelolaan sampah rumah tangga yang bermanfaat RW 07 Kelurahan Sungai Pelunggut Kecamatan Sagulung Kota Batam .

c. Masalah-masalah yang timbul dalam pengelolaan sampah rumah tangga RW 07 Kelurahan Sungai Pelunggut Kecamatan Sagulung Kota Batam dengan cara ecoenzim.

\section{PEMBAHASAN}

Limbah sejak dulu menjadi masalah bagi kehidupan manusia. Berdasarkan keputusan Menperindag RI No. 231/MPP/Kep/7/1997 Pasal I tentang prosedur impor limbah, menyatakan bahawa Limbah memiliki pengertian bahwa Limbah adalah bahan/barang sisa atau bekas dari suatu kegiatan atau proses produksi yang fungsinya sudah berubah dari aslinya, kecuali yang dapat dimakan oleh manusia dan hewan.

Limbah dibedakan menjadi 2 berdasarkan toksisitasnya, yaitu limbah non B3 dan limbah B3 (Bahan Berbahaya dan Beracun). Limbah non B3 adalah limbah yang tidak memberikan dampak bagi makhluk hidup. Sementara limbah B3 adalah limbah yang mengandung bahan berbahaya dan beracun karena sifat, konsentrasi dan jumlahnya baik secara langsung maupun tidak langsung dapat merusak, mencemarkan lingkungan hidup, dan dapat mebahayakan manusia dan makluk hidup lingkugan sekitarnya. Berdasarkan asalnya limbah, dibagi ke dalam 3 kelompok, yaitu limbah rumah tangga, limbah pertanian, dan limbah industri. Oleh krena itu untuk memanfaatkan limbah rumah tangga sebagai benda yang bermanfaat dan mempunyai nilai guna. Sosialisasi kali ini tidak hanya menambah wawasan tentang pelestarian lingkungan, tetapi juga mengingatkan para relawan bahwa 
pelestarian lingkungan bisa dimulai dari hal-hal yang kecil. Maka dari itu kami menghadirkan system pengeloaan sampah dengan memanfaatkan kulit buah-buahan dengan istilah ecoenzim.

Ekoenzim menggunakan bahan baku yang mudah didapat dan murah. Proses fermentasinya yang selama 3 bulan, memang membutuhkan kesabaran tersendiri. Namun, larutan yang dihasilkan memiliki khasiat yang sangat banyak. Dalam proses fermentasinya saja, sudah terus dihasilkan gas $\mathrm{O}_{3}$ (ozon) yang sangat dibutuhkan atmosfer bumi. Larutan ekoenzim bila dicampur dengan air, akan bereaksi serta dapat digunakan sebagai cairan pembersih mulai dari piring, lantai, pakaian, kakus, sampai dengan pencuci rambut dan sabun mandi. Disamping itu, campuran dengan air bila digunakan untuk menyiram tanaman akan memberi hasil buah, bunga, atau panen yang lebih baik. Kabarnya juga dapat mengusir serangga-serangga pengganggu. Ampas sampah organik yang sudah difermentasi bisa digunakan sebagai pupuk organik yang baik.

\section{Cara membuat ekoenzim:}

Cara pembuatan ekoenzim tidak begitu sulit untuk diterapkan karena menggunakan bahan-bahan yang sudah sangat kita kenal. Untuk membuat ekoenzim kita harus menyiapkan bahan -bahan sperti dibawah ini:
a. Air bersih
b. Gula jawa/gula aren
c. Sampah organik (kulit buah/sayur)
d. Botol/jeriken plastik (jangan gunakan bahan kaca)

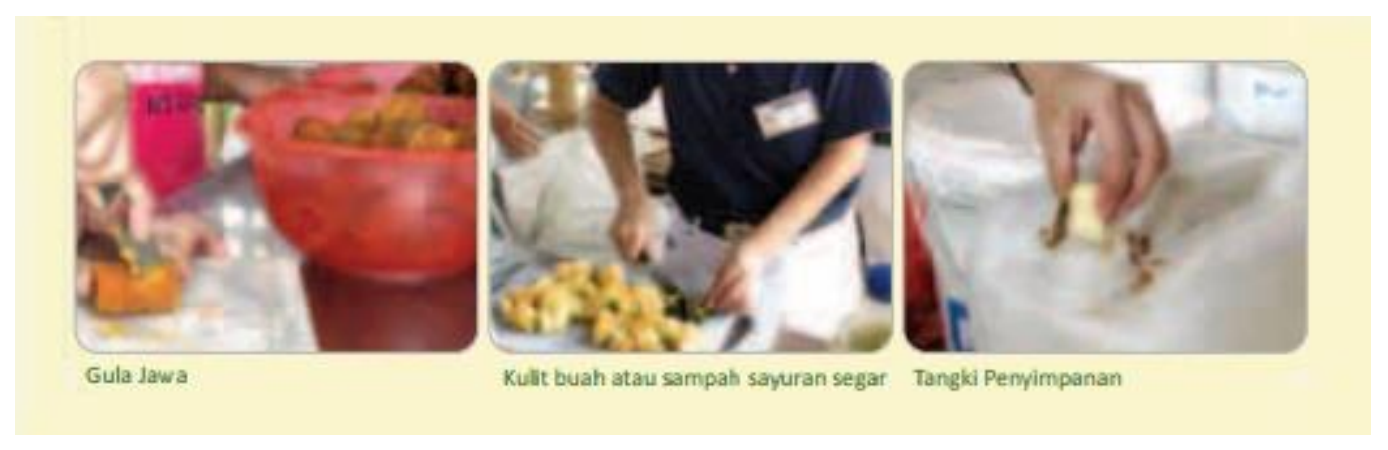

Gambar 1. Pembuatan Ekoenzim 
Perbandingan air : gula : sampah organik $=10: 1: 3$

\section{Langkah-langkah:}

Adapun langkah-kangkah yang harus kita lakukan adalah sebagai berikut;

a. Masukkan air ke dalam botol yang mempunyai tutup yang rapat. Air tidak boleh mengisi penuh botol, harus tersisa ruang dalam botol untuk gas hasil fermentasi.

b. Potong kecil gula, masukkan ke dalam botol, lalu kocok sebentar.

c. Masukkan potongan sampah organik ke dalam botol, lalu tutup rapat-rapat.

d. Diamkan selama 3 bulan agar proses fermentasi sempurna dan menghasilkan ekoenzim.

Dengan catatan bahawa Selama 1 bulan pertama, buka tutup botol setiap hari paling lama 5 detik, untuk membebaskan gas hasil fermentas.

\begin{tabular}{|c|r|r|}
\hline \multirow{2}{*}{ Pemakaian } & \multicolumn{2}{|c|}{ Perbandingan } \\
\cline { 2 - 3 } & $\begin{array}{r}\text { Larutan } \\
\text { ekoenzim }\end{array}$ & Air \\
\hline Mencuci piring & & 10 \\
\hline (dapat dicampur sedikit sabun cuci \\
piring cair agar berbusa) & 1 & 200 \\
\hline Penyegar udara & & 500 \\
\hline Menyiram tanaman & 1 & 500 \\
\hline Disinfektan & 1 & 1.000 \\
\hline Mengepel lantai & 1 & \\
\hline
\end{tabular}

\section{Tabel 1. Takaran Pemakaian Ekoenzim}

Ekoenzim yang menggunakan bahan baku yang mudah di dapat dan murah. Proses fermentasinya yang selama bulan, memang membutuhkan kesabaran. Namun, larutan yang dihasilkan memiliki khasiat yang sangat banyak. Dalam proses fermentasinya saja, sudah terus dihasilkan gas 03 (ozon) yang sangat dibutuhkan atmosfer bumi. Larutan ekoenzim bila dicampur dengan air, akan bereaksi serta dapat digunakan sebagai cairan pembersih mulai 
dari piring, lantai, pakaian, kakus, sampai dengan pencuci rambut dan sabun mandi. Bila butuhkan, juga bisa melancarkan saluran air yang tersumbat. Bila digunakan untuk menyiram tanaman akan memberi hasil buah, bunga, atau panen yang lebih. Disamping itu juga dapat mengusir serangga-serangga pengganggu. Ampas sampah organik yang sudah difermentasi bisa digunakan sebagai bahan untuk kebersihan dan juga sebagai pupuk organik yang baik.

Tiga bulan mendatang, cairan dalam jerigen ini dapat digunakan untuk beragam fungsi, dan ampas sampah buahnya dapat digunakan sebagai pupuk organik. Selain untuk pupuk juga bias digunakan untuk pengepel lantai rumah, hasilnya lantai tidak licin meskipun tidak memkai sabun. Padahal anak-anak atau anggota keluarga sering mengunakan lantai. Dengan hanya memakai 2 tutup botol enzim dicampur 1 ember air. Selain itu ekoenzim bias dibuat sangat mudah.

\section{KESIMPULAN}

Kegiatan pembuatan sampah organik menjadi bahan berguna bagi warga baik untuk kesehatan dan kebrsihan dilaksanakan berdasarkan program kerja KKN-PPM kelompok 17 pada tahun 2017, hingga hasil kerjanya, maka kami menyimpulkan bahwa dengan kehadiran mahasiswa KKN. PPM terasa cukup membantu masyarakat RW 07 Kec.Sagulung Kota Batam. Dengan memanfaatkan limbah rumah tangga yang bias bermnafaat sebagai pengganti produk-produk kimia industri. Selain ramah lingkungan limbah rumah tangga bisa menjadikan nilai ekonomis bagi warga RW $07 \mathrm{Kec}$.Sagulung Kota Batam karena selain lingkungan menjadi bersih juga tidak memerlukan biaya yang mahal untuk memperolehnya. Dengan memperkenalkan pengelolan limbah rumah tangga dengan ekoenzim.

Ekoenzim adalah dengan menggunakan bahan baku yang mudah di dapat dan murah. Proses fermentasinya yang selama bulan, memang membutuhkan kesabaran. Namun, larutan yang dihasilkan memiliki khasiat yang sangat banyak. Dalam proses fermentasinya saja, sudah terus dihasilkan gas 03 (ozon) yang sangat dibutuhkan atmosfer bumi. Manfaat yang ada dari ekoenzim adalah bisa melancarkan saluran air yang tersumbat. Elain itu, bisa juga digunakan untuk menyiram tanaman akan memberi hasil buah, bunga, atau panen yang lebih 
dan dapat mengusir serangga-serangga pengganggu. Ampas sampah organik yang sudah difermentasi bisa digunakan sebagai bahan untuk kebersihan dan juga sebagai pupuk organik yang baik.

\section{REFERENSI}

Alexander Abe, 2001. Perencanaan Daerah Memperkuat Prakarsa Rakyat Dalam Otonomi Daerah. Yogyakarta: Lapera Pustaka Utama,

Departemen Pekerjaan Umum, 2008. Perencanaan Teknis Pengelolaan Sampah Terpadu 3R,

Departemen Pekerjaan Umun Kota Semarang.Hadi, S.P. 2004, . Aspek Sosial Amdal.Gadjah Mada UniversityYogyakarta.

Yusuf, Guntur. 2008. Bioremediasi Limbah Rumah Tangga Dengan Sistem Simulasi Tanaman Air. Jurnal Bumi Lestari, Vol. 8 No. 2, Agustus 2008. Hal. 136-144

Slamet J,S, 2002. Kesehatan Lingkungan. Gadjah Mada Universty Press, Yogyakarta.

Syafrudin,2004. Pengelolaan Sampah Berbasis Masyarakat.Prosiding Diskusi .Interaktif Pengelolaan Sampah Terpadu, Program Magister Ilmu Lingkungan Universitas Diponegoro.

LPPM, 2017. .Buku Pedoman Kuliah Kerja Nyata Unrika Batam 2017. Batam: Unrika Press

http://eprints.undip.ac.id/18387/1/Ni_Komang_Ayu_Artiningsih.pdf. html.26 September 2017pukul 07.28

http://www.tzuchi.or.id/ruang-hijau/ekoenzim-larutan-ajaib-dari-sampah organik/html.26September pukul07.34

https://dhammacitta.org/forum/index.php?topic=18234.0. html. 26 September 2017 pukul07.55 